\title{
Antecedents of professionals' self-efficacy in professional service firms: effects of external source credibility and content quality
}

\author{
Fabio Cassia \\ Department of Business Administration, University of Verona, Verona, Italy, and \\ Francesca Magno \\ Department of Management, University of Bergamo, Bergamo, Italy
}

\begin{abstract}
Purpose - Professional service firm (PSF) performance depends on the accumulation and application of specialist knowledge to find customised solutions to customer problems. However, available research has not examined whether knowledge acquired from external sources affects PSF outcomes by strengthening professionals' beliefs rather than only by increasing technical competency. Drawing on self-efficacy theory, this study tests a model that links the quality of content acquired from external sources and the credibility of those sources to professionals' self-efficacy and, in turn, to PSF outcomes (solution quality and firm performance). In particular, this paper aims to consider the case of professional content exchanged through professional social media.

Design/methodology/approach - A cross-sectional research design was applied. Data were collected from a sample of 208 accountants, auditors and lawyers who used professional social media and were analysed using covariance-based structural equation modelling.

Findings - When accessing professional content from external sources, source credibility and content quality are significant antecedents of professionals' self-efficacy, which, in turn, has positive effects on PSF outcomes (solution quality and PSF performance).

Research limitations/implications - Self-efficacy plays a key role in the link between knowledge acquired from external sources (professional content) and PSF outcomes.

Practical implications - This study provides recommendations and actionable insights for PSFs, professionals and other actors who create and exchange professional content. Professional associations may also take an active role by contributing and sharing credible and high-quality content, using, for example, professional social media.

Originality/value - This paper advances the current understanding of the effects of professionals' access to content from external sources on PSF outcomes. It provides an explanation of these effects based on the enhancement of professionals' beliefs instead of their technical competencies, as indicated in previous research. In addition, it is the first research effort to consider professional social media as a communication channel to exchange content that affects the self-efficacy of PSF professionals.
\end{abstract}

Keywords Self-efficacy, Performance, Professional service firms, Value creation, Knowledge management, Professional social media

Paper type Research paper

\section{Introduction}

The value creation process in professional service firms (PSFs) relies on the accumulation and application of professionals' specialist knowledge to provide customised solutions to customers' specific problems (Aarikka-Stenroos and Jaakkola, 2012; Bettencourt et al., 2002; Heikka and Nätti, 2018; Still et al., 2018). Thus, knowledge intensity is the most significant and distinctive characteristic of PSFs and is a key determinant of market performance and competitive advantage (BrandonJones et al., 2016; Madhavaram and Hunt, 2017; Still et al., 2018; Von Nordenflycht, 2010).

The current issue and full text archive of this journal is available on Emerald Insight at: https://www.emerald.com/insight/0885-8624.htm

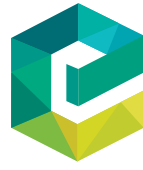

Journal of Business \& Industrial Marketing 36/13 (2021) 187-198

Emerald Publishing Limited [ISSN 0885-8624] [DOI 10.1108/JBIM-11-2019-0485]
Prior studies have investigated the sources of professionals' specialist knowledge, highlighting the role of extensive education and training prior to working in the field (Hausman, 2003; Hitt et al., 2001), ongoing training (Fu et al., 2019), internal relations or social capital (Madhavaram and Hunt, 2017), past experience (Desyllas et al., 2018; Jaakkola and Halinen, 2006), professional journals and magazines (Cassia and Magno, 2012), interactions

\footnotetext{
(C) Fabio Cassia and Francesca Magno. Published by Emerald Publishing Limited. This article is published under the Creative Commons Attribution (CC BY 4.0) licence. Anyone may reproduce, distribute, translate and create derivative works of this article (for both commercial and non-commercial purposes), subject to full attribution to the original publication and authors. The full terms of this licence may be seen at http://creativecommons.org/licences/by/4.0/legalcode
}

Received 16 November 2019

Revised 30 April 2020

18 August 2020

22 November 2020

28 February 2021

Accepted 1 April 2021 
with customers (Aarikka-Stenroos and Jaakkola, 2012; Fosstenløkken et al., 2003) and face-to-face interactions among peers (Hitt et al., 2001).

However, few studies have examined how new specialist knowledge from outside the boundaries of PSFs affects PSF performance (Siahtiri et al., 2020). Moreover, these studies have not considered that access to new knowledge may influence PSF value creation and outcomes via psychological mechanisms (i.e. by acting on professionals' perceptions and beliefs). When developing solutions for customers, professionals are often confronted with remarkable complexity and unpredictable events and outcomes (Madhavaram and Hunt, 2017), and may seek external knowledge to mitigate their uncertainty and anxiety (Aarikka-Stenroos and Jaakkola, 2012). Prior studies have focused on the effect of new knowledge on PSF performance through the improvement of technical competency (Siahtiri et al., 2020) and productivity (Khaksar et al., 2020), but have not evaluated whether this new knowledge can also influence PSF outcomes by strengthening professionals' self-belief and selfconfidence. By evaluating professionals' beliefs about source credibility and quality of the content exchanged through professional social media and used to solve customers' everyday problems, this is the first study to consider how external sources of specialist knowledge indirectly influence PSF performance through psychological mechanisms. Having a better understanding of the psychological mechanisms that drive a professional's performance is not only crucial to advance theoretical knowledge about PSF value creation processes but also provides PSF managers and professional associations with tools to help their employees/members feel the confidence needed to perform at their best.

This study develops a model that proposes that professionals' perceptions about source credibility and the quality of the content accessed from external sources are related to professionals' self-efficacy beliefs - "the conviction that one can successfully execute the behaviour required to produce the outcome" (Bandura, 1977, p. 193) - which in turn affect PSF outcomes. The study builds on self-efficacy theory (Bandura, 1977, 1999; Bandura et al., 1977), which offers an explanation for the antecedents of an individual's performance when facing an uncertain or difficult task or situation. According to this theory, outcomes depend on an individual's self-efficacy, which is driven by four antecedents (Bandura, 1977), two of which are internal (past performance accomplishments and emotional arousal) and two of which are external (vicarious experience and verbal persuasion) to the individual's sphere. From these four sources, an individual forms a perception about his or her self-efficacy, which has a direct effect on outcomes.

Consistent with this theory, this study focuses on the external antecedents of professionals' self-efficacy to explore how new specialist knowledge from outside the boundaries of PSFs affects PSF performance. To develop stronger arguments, we then integrate self-efficacy theory with the theory of informational support, which specifically addresses situations in which an individual receives advice and suggestions about possible solutions to a problem (Cutrona, 1990; Guan and So, 2016; Zha et al., 2018). In particular, the research setting selected to test the suggested model considers professional content exchanged among professionals through professional social media.
The remainder of this paper is structured as follows: The research background is provided in Section 2, incorporating an overview of PSFs and their value creation processes, and highlighting the role of knowledge acquired from external sources. Then, a summary of self-efficacy theory and its tenets are presented and then integrated with the theory of informational support. Second, the research model and hypotheses are presented in Section 3, followed by a description of the methods in Section 4, and data analysis and results in Section 5. The paper concludes with theoretical and managerial implications and a discussion of the research limitations in Section 6.

\section{Research background}

\subsection{Professional service firms and their value creation processes}

Professional services have long been distinguished as a specific type of service (Miles, 1993). Initially, this distinction was based on the specific service delivery process, which is characterised by three features: high customer contact, meaning that customers actively intervene in the service process; high customisation, reflecting a focus on satisfying an individual's particular preferences; and labour intensity (Schmenner, 1986). Despite the value of this conceptualisation, several scholars (Verma, 2000) have suggested the need to develop a more nuanced understanding of professional services.

Over the past three decades, the transition towards a knowledge-based economy and view of firms (Barney, 1991; Grant, 1996; Nickerson and Zenger, 2004) has offered new insights into the nature of PSFs (Hitt et al., 2001). The knowledge-based view suggests that the performance of a firm is related to its ability to integrate the specialist knowledge of individuals into the delivery of goods and services (Grant, 1999). Hence, the core activities of firms include the creation, acquisition, storage and deployment of knowledge (Grant, 1996). Drawing on this framework, studies have suggested that knowledge intensity is the most important distinctive characteristic of PSFs (Castaldi and Giarratana, 2018; Von Nordenflycht, 2010), while other features such as high labour intensity may vary significantly between diverse types of PSF (Brandon-Jones et al., 2016). While classic PSFs such as accounting firms are typically characterised by knowledge intensity, high labour intensity and a professionalised workforce, knowledge intensity is the only characteristic shared by all types of PSF, including classic PSFs, technology developers (e.g. research and development laboratories), neo-PSFs (e.g. advertising agencies) and professional campuses (e.g. universities) (Von Nordenflycht, 2010).

Knowledge intensity means that a PSF's value creation process relies on a substantial body of complex knowledge embodied by its professionals (Heikka and Nätti, 2018). More precisely, the value of professional services arises from joint problem-solving processes in which both professionals and customers contribute complementary resources (AarikkaStenroos and Jaakkola, 2012; Grönroos, 2011; Heirati et al., 2019; Løwendahl, 2005; Vargo and Lusch, 2016). Customers provide professionals with information about their needs and goals, while professionals contribute their specialised knowledge, including diagnostic skills, professional judgements 
and methods and tools, to identify problems and develop solutions (Aarikka-Stenroos and Jaakkola, 2012). Hence, the performance of PSFs is directly related to the ability of professionals to continually enhance and transform their knowledge to solve customers' problems (Hogan et al., 2011).

From the perspective of professionals, developing successful solutions for customers is a challenging process, characterised by uncertainty, ambiguity and anxiety (Aarikka-Stenroos and Jaakkola, 2012; Still et al., 2018). Professionals continually learn from experience throughout their careers, allowing them to accumulate knowledge and reduce uncertainty (Hitt et al., 2001). However, they often face scenarios in which their knowledge is insufficient to address a specific problem, and thus may refer to external sources to access information, suggestions and feedback (Asare et al., 2020; Siahtiri et al., 2020).

When seeking to complement their knowledge, professionals rely on several sources, among which interactions with peers have a prominent role as a trusted source of information (Blair et al., 2019; Brandon-Jones et al., 2016). In this study, we specifically focus on the content exchanged among peers, and for the empirical analysis, we consider one of the communication channels through which these exchanges take place, namely, professional social media. While several other channels may be used by professionals (including direct, face-to-face interactions as shown in past studies (Hitt et al., 2001), we consider professional social media for its growing popularity and potential to enable interactions and exchanges. As suggested by the theory of technology platforms, social media can facilitate interactions and transactions among engaging actors, with positive effects in terms of enhancement of the business model (Rodríguez et al., 2020). By engaging on these platforms, firms can access knowledge outside their own boundaries and integrate it with their internal knowledge to improve value creation (Andreassen et al., 2018; Lichtenthaler and Lichtenthaler, 2009).

Research on the mechanisms through which knowledge acquired from peers and external sources improves solutions and the overall performance of PSFs is scant. A recent study by Siahtiri et al. (2020) indicates that external knowledge can improve technical competency in developing successful solutions and, in turn, solution performance. However, available research has not examined whether knowledge acquired from external sources affects PSF outcomes through professionals' beliefs rather than through technical competency. Given the central role of professionals' emotions and beliefs in the value creation process of PSFs, the existence of such a mechanism seems reasonable and likely (Sturdy, 1997). This study highlights the central role of a specific type of belief - self-efficacy - by drawing on self-efficacy theory, discussed in the following section. That is, this research does not focus on functional benefits related to the acquisition of technical knowledge, but aims to explain the effects on PSF performance by examining the psychological benefits from professional content exchange.

\subsection{Self-efficacy theory and theory of informational support} Self-efficacy theory explains the antecedents of a person's performance or outcomes when facing an uncertain or difficult task or situation (Bandura, 1986, 1999). The theory proposes that the outcomes in such cases directly depend on a person's level of self-efficacy; that is, the belief that one has the ability to successfully execute a task (Figure 1). People with high levels of
Figure 1 Theory of self-efficacy

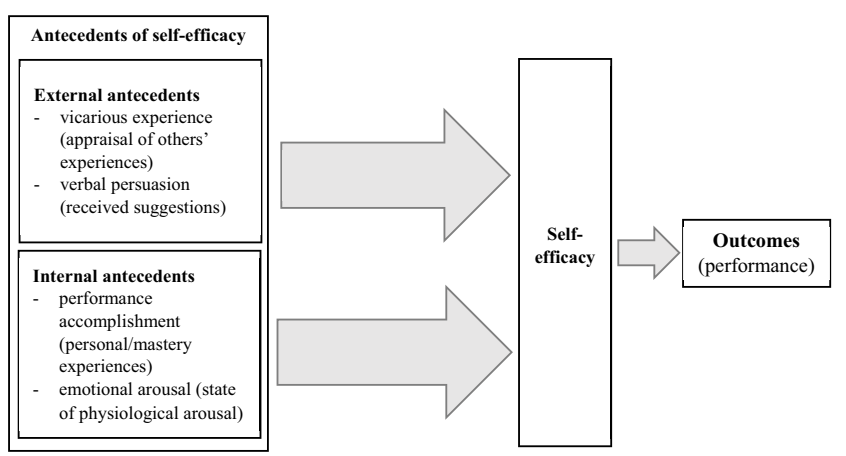

self-efficacy approach difficult tasks as challenges to be mastered, thus achieving better outcomes (Bandura, 1999). In contrast, those with low self-efficacy approach uncertain situations anxiously, hindering performance (Bandura, 1986).

The theory identifies four antecedents (or sources) of selfefficacy, two of which (performance accomplishments and emotional arousal) are internal and two of which (vicarious experience and verbal persuasion) are external to the individual's sphere (Bandura, 1977; Bandura et al., 1977). The first antecedent - performance accomplishments - refers to an individual's past successful experiences (or mastery of experience) in dealing with similar tasks, which is highly effective in building self-efficacy. The second - emotional arousal - refers to an individual's physiological state, which may result in either positive or negative effects on self-efficacy (e.g. medium levels of arousal improve self-efficacy, while excessive levels of arousal reduce self-efficacy). The third antecedent vicarious experience - refers to observations of other people's accomplishments or learning from the experiences of others, who act as models affecting the observer's perception of his or her self-efficacy. The final antecedent - verbal persuasion involves receiving suggestions and feedback from others, which affects an individual's belief that he or she can cope successfully with a task. In addition, particularly with respect to external antecedents (vicarious experience and verbal persuasion), research has highlighted that peers' experiences and suggestions strongly influence the development of self-efficacy (Schunk, 1989).

Over the years, self-efficacy theory has demonstrated broad applicability (Bandura, 1986). In the business context, it has been extensively applied to explain managers' decisions and salespeople's performance based on their levels of self-efficacy (Brown et al., 2005; Liang, 2019). Overall, these studies have found that managers and salespeople with higher levels of selfefficacy are more effective in coping with complex situations and tasks and succeed because of greater persistence. Other studies in the context of value co-creation have shown that selfefficacy directly influences actors' intentions to take part in value co-creation processes (Xie et al., 2008).

In this paper, the theory of self-efficacy is integrated with the theory of informational support to explain how vicarious experience and verbal persuasion (i.e. the two external antecedents) affect self-efficacy (Figure 2). According to the framework of social support (Cutrona, 1990; Cutrona and Russell, 1990), informational support "refers to when an 
Figure 2 The integration between the theories of self-efficacy and informational support

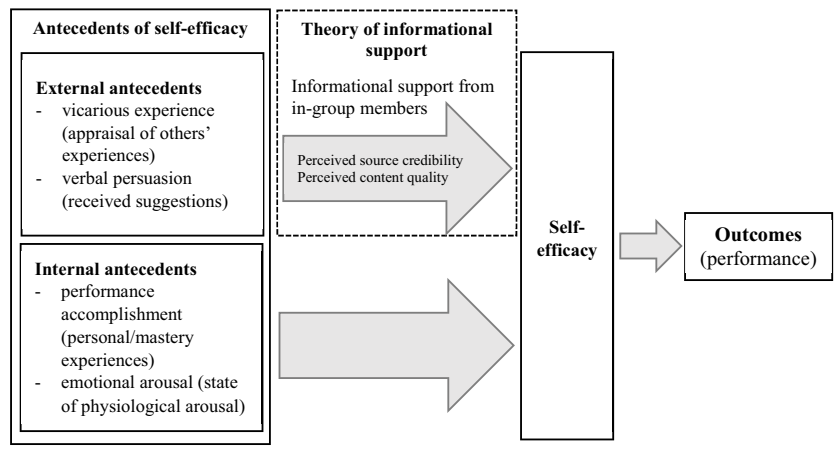

individual receives advice, guidance, or suggestions regarding possible solutions to a problem" (Guan and So, 2016, p. 592). Such support is stronger when it comes from in-group members (peers), and directly influences self-efficacy.

Informational support has been widely acknowledged as a key benefit of interactions among peers (Kaplan and Haenlein, 2010). In this context, informational support is conceptualised through content or argument quality and source credibility (Zha et al., 2018), where source credibility indicates "the extent to which an information source is perceived to be believable, competent and trustworthy by information recipients" (Bhattacherjee and Sanford, 2006, p. 811), while content quality concerns content "completeness, accuracy and currency" (Zha et al., 2018, p. 230). Drawing on this theoretical background, the next section presents the research model.

\section{Model and hypotheses}

The model presented in this study illustrates the effects of external source credibility and content quality on professionals' self-efficacy and, in turn, on PSF outcomes, namely, solution quality and performance (Figure 3 ).

The model directly draws on the theories of self-efficacy and informational support by considering the exchanged content as a source of both vicarious experience and verbal persuasion. Consistent with Anderson's (2006) long tail theory, by interacting with their peers, professionals may be more likely to find other professionals who have already experienced similar niche problems and can thus provide advice. In particular, available communication channels such as professional social media allow professionals to access distal knowledge (Siahtiri et al., 2020) by interacting with peers outside of their personal

\section{Figure 3 Research model}

Antecedents of self-efficacy

Outcomes of self-efficacy

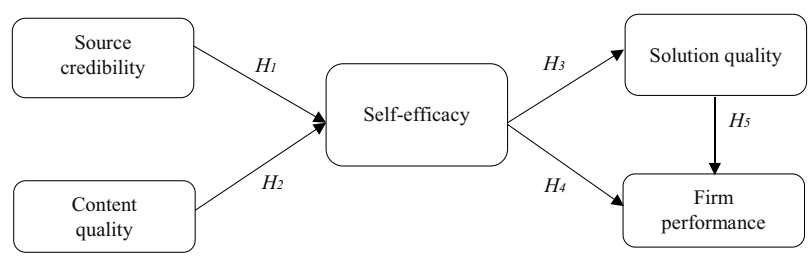

networks and asking for suggestions and feedback. Such interactions also strengthen professionals' social identity - that is, the sense of belonging to a community (Wang et al., 2016) which emphasises the perceptions of informational support from the community (Guan and So, 2016).

The first part of the model (i.e. the antecedents of selfefficacy) directly draws on the two dimensions highlighted by the theory of informational support: source credibility and content or argument quality (Zha et al., 2018).

When a source of information is believed to be credible, a person is more likely to trust it, accept its message and engage in a process of learning (Nguyen et al., 2015; Willemsen et al., 2012). Self-efficacy theory highlights that the more credible the source of information, the more likely that efficacy expectations will change. At a broader level, it also provides evidence of the influence of credibility on attitudinal change (Bandura, 1977; Bohner and Dickel, 2011). The effects of source credibility on user attitudes are well documented - messages from credible sources are more persuasive than those from non-credible sources (Cosenza et al., 2015). Research focusing on professional online communities suggests that trust fosters interactions leading to changes in participants' attitudes, such as engagement (Wang et al., 2016). More specifically, prior analyses prove the positive link between informational support and self-efficacy (Guan and So, 2016). Hence, it is argued that if professionals perceive the source of the professional content as reliable, they will be more likely to engage in exchange (Kolb and Kolb, 2009), leading to changes in their service selfefficacy. In fact, as supported by social identity theory, the perception of having access to credible sources activates a psychological process through which professionals construct and maintain their professional identity, with the result of improving their self-concept, self-esteem and perceived ability to accomplish their tasks (Brouard et al., 2017; Warren and Parker, 2009).

Therefore, it is suggested that:

H1. Source credibility has a positive effect on a professional's self-efficacy.

Content quality, the other dimension of informational support (Zha et al., 2018), consists of the utilitarian assessment of accessed information (Magno, 2017). Studies drawing on selfefficacy theory have shown that the quality of received information is positively and directly related to changes in selfefficacy (Van Beuningen et al., 2011). In fact, the quality of the exchanged content, such as its accuracy, is essential for motivating users to engage with that content (Aladwani, 2017). The link between social support, including informational support, and self-efficacy has also been specifically proved (Guan and So, 2016). Research also provides evidence showing that the impacts of content quality on users' attitudes are more intense in professional contexts than in business-to-consumer (B2C) contexts (Zhang and Du, 2020). Though previous studies have not specifically considered the case of PSFs and professionals, we may expect that the quality of professional content accessed from external sources has similar effects. Available research indicates that PSFs assimilate new external knowledge if they recognise that it is new and valuable (Khaksar et al., 2020). Then, if they perceive the external content as being of high quality, professionals are more likely to engage in 
transaction and learning processes (Kolb and Kolb, 2009). Such processes reinforce the perception of having the capabilities to master specific customer problems. Consist with these arguments, it is suggested that:

H2. Content quality has a positive effect on a professional's self-efficacy.

Service research has found that employees' self-efficacy is directly and positively related to a variety of organisational outcomes (Gist, 1987; Yim et al., 2012), including service quality (Hartline and Ferrell, 1996; Robinson et al., 2011). Indeed, when service providers strongly trust their own abilities, they are more likely to deliver higher-quality service (Hartline and Ferrell, 1996). PSFs aim to deliver high-quality solutions, defined as finding "the right solution for the problem encountered" (Atuahene-Gima, 2003, p. 359). To fulfil this aim, the value co-creation process consists of problem-solving activities that range from diagnosis to resolution (Hogan et al., 2011). In PSFs, customer problems are often complex and unique, meaning that professionals must employ significant effort and resources to develop high-quality customised solutions (Heirati et al., 2016; Siahtiri et al., 2020). As suggested by selfefficacy theory (Bandura, 1977), the outcomes of dealing with such complex tasks directly descend from a professional's selfefficacy. Therefore, it is hypothesised that:

H3. A professional's self-efficacy is positively related to solution quality.

Extensive research in marketing and sales has highlighted the link between managers' and salespeople's self-efficacy and performance (Anderson et al., 2008; Fu et al., 2010). Similarly, studies have shown that the self-efficacy of entrepreneurs and owners has a direct influence on firm performance, especially in small- and medium-sized enterprises (Khedhaouria et al., 2015; Poon et al., 2006). Irrespective of their size, PSFs are characterised as being people-centred (McColl-Kennedy et al., 2008), thus emphasising the link between PSF performance and human capital (Greenwood et al., 2005). On this point, Heikka and Nätti (2018) note that customer relationships in PSFs are highly "personified", and professionals directly influence market performance. Therefore, it is hypothesised that:

H4. A professional's self-efficacy is positively related to firm performance.

Prior knowledge about professional services indicates that a professional's ability to develop a successful solution for a customer's problem is the most important driver of customer satisfaction and loyalty (Pemer and Skjølsvik, 2019). By tailoring solutions to meet demand, PSFs can secure the loyalty of valuable customers (Desyllas et al., 2018). This ability also enhances the credibility of a PSF's expertise, thus attracting new customers (Casidy et al., 2018). Consequently, the ability of a PSF to apply its knowledge base to develop effective solutions for its customers is positively related to its market and financial performance (Løwendahl, 2005; Løwendahl et al., 2001; Macdonald et al., 2016). Therefore, it is hypothesised that:

H5. Solution quality is positively related to firm performance.

\section{Methods}

\subsection{Research context, data collection and sample description}

This study adopted a cross-sectional approach using a questionnaire-based survey. A survey sample of 1,143 Italian accountants, auditors and lawyers was compiled by consulting Italian public registries, which included approximately 100,000 certified accountants and auditors and 242,000 lawyers (Cassia and Magno, 2012; Censis, 2018). The average size of these PSFs is remarkably small: official statistics (FNC, 2018) indicate that $71 \%$ have $1-5$ employees and $17.4 \%$ have $6-10$ employees (with the relatively small remainder having $>10$ employees). Sample selection was based on a stratified sampling technique that reflected both the professionals' level of experience (number of years since accountants or auditors had been certified or lawyers had received their licences) and geographical location. Selected accountants, auditors and lawyers were contacted by email with a written description of the purpose of the research project, an invitation to participate in the survey and a link to the online questionnaire. After two recalls (two and three weeks after the initial invitation), 501 questionnaires were received.

For the purposes of this study, we considered professional social media the source of professional content and therefore retained only those respondents $(n=208)$ who stated that they used this communication channel. The decision to consider social media instead of other sources of content was driven by several factors. The choice of professional social media platforms (instead of other communication channels available to professionals) as the communication channel for this study is driven by three considerations. First, professional social media platforms facilitate interactions and content exchange and cocreation in business settings (Conde et al., 2020; Paschen et al., 2019). In particular, the theory of technology platforms indicates that technological platforms such as social media facilitate interactions and transactions among the actors, thus enhancing value creation (Rodríguez et al., 2020). Second, they encompass both of the external antecedents of self-efficacy outlined in self-efficacy theory: vicarious experience (i.e. observing the experiences of peers who have developed solutions for similar problems) and verbal persuasion (i.e. receiving suggestions and feedback from peers about a specific problem). Third, professional social media platforms are gaining popularity among professionals. For example, the American Institute of Certified Public Accountants provides advice for "Engaging in social media with other accountants" (www.aicpa.org), suggesting, for example, that accountants join LinkedIn discussion groups to seek advice. Specific professional social networks such as Foxwordy, a social network for lawyers that enables collaboration and the exchange of ideas and advice between peers, and countless specialised professional blogs are also gaining popularity. Finally, by considering only one specific channel of communication, we aimed to obtain more precise results.

Drawing on Iankova et al.'s (2019) conceptualisation, only pure professional social media, including professional social networks, blogs, forums and message boards, and collaborative projects (Kaplan and Haenlein, 2010), were considered, while 
B2C and mixed B2C/business-to-business (B2B) forms of social media were excluded. Most participants reported using forums and social media pages of significant PSFs or professional magazines and databases such as Commercialista Telematico (https://forum.commercialistatelematico.com/) and the LinkedIn group Dottori Commercialisti ed Esperti Contabili. Respondents' firms were mostly small in size, with 156 firms having $\leq 5$ employees, 43 firms having 6-10 employees and only 9 firms having $>10$ employees.

\subsection{Measures}

All constructs were measured using multiple items taken from past studies and slightly adapted to the research context. Source credibility was measured using three items adapted from Kim et al. (2018); content quality was measured using three items adapted from Magno (2017); service self-efficacy was measured using four items adapted from Lee (2014); solution quality was measured using three items adapted from Atuahene-Gima (2003) and Madhavaram and Hunt (2017); and firm performance was assessed using five items adapted from Tajvidi and Karami (2017). Source credibility was measured using a five-point semantic differential scale, while all other constructs were measured using a five-point Likert scale. Likert scales ranged from 1 (totally disagree) to 5 (totally agree) for all constructs except firm performance, which ranged from 1 (very poor) to 5 (outstanding). The complete list of items is shown in Table 1 . In addition, frequency of social media use, measured on a five-point scale from 1 (rarely) to 5 (often), was included as a control variable to assess whether a relationship existed between frequency of social media usage and selfefficacy.
Absence of non-response bias was assessed by comparing early and late respondents using $t$-tests, as suggested by Armstrong and Overton (1977). The analysis indicated no significant difference between questionnaires received before and after the first recall (two weeks after the initial invitation). Moreover, the principal component factor analysis highlighted five distinct factors and none of them accounted for the majority of the variance, indicating that common method variance was not an issue (Podsakoff et al., 2003).

Finally, assumptions of normality, linearity and homoscedasticity required by covariance-based structural equation modelling were verified (Hair et al., 2011; Kline, 2011).

\subsection{Measurement model}

Confirmatory factor analysis was used to evaluate the measurement model (Table 1), revealing a good overall fit (Bagozzi and Yi, 2012). Specifically, the $\chi^{2} / d f$ ratio was 1.89 , well below the cut-off value of 3. Comparative fit index (CFI) was 0.96, well above the suggested threshold of 0.93 (Bagozzi and $\mathrm{Yi}, 2012$ ). Finally, root mean square error of approximation (RMSEA) was 0.06 , below the recommended level of 0.07 (Bagozzi and Yi, 2012).

Further, all standardised factor loadings were higher than the cut-off value of 0.70 . For each construct, the composite reliabilities were above 0.70 , and the average variances extracted were higher than 0.50 . Finally, the average variances extracted for each latent construct were greater than the construct's highest squared correlation with any other construct, showing satisfactory discriminant validity (Fornell and Larcker, 1981) (Table 2). Hence, reliability, convergent

Table 1 Measurement model

\begin{tabular}{|c|c|c|c|c|c|}
\hline Construct & Item & Mean & $S D$ & CR & Factor loading \\
\hline Source credibility & \multicolumn{5}{|l|}{ The professional social media I use is: } \\
\hline \multirow[t]{3}{*}{ (Kim et al., 2018) } & Unknowledgeable_-knowledgeable & 2.84 & 0.96 & & 0.88 \\
\hline & Unqualified-qualified & 3.11 & 0.95 & 14.52 & 0.83 \\
\hline & Inexperienced-experienced & 2.79 & 0.87 & 11.54 & 0.75 \\
\hline Content quality & The information provided by the professional social media I use is accurate & 3.23 & 1.12 & & 0.92 \\
\hline \multirow[t]{2}{*}{ (Magno, 2017) } & The content of the professional social media I use is updated & 3.25 & 1.10 & 15.42 & 0.92 \\
\hline & The social media I use provides high-quality information & 3.20 & 1.06 & 15.32 & 0.71 \\
\hline \multirow{4}{*}{$\begin{array}{l}\text { Self-efficacy (Lee, } \\
\text { 2014) }\end{array}$} & I possess the capabilities needed to deliver excellent services to customers & 2.53 & 1.13 & & 0.71 \\
\hline & I can perform my service tasks accurately & 2.49 & 1.05 & 10.78 & 0.80 \\
\hline & I can perform my service tasks in accordance with customers' needs & 2.45 & 1.00 & 11.86 & 0.87 \\
\hline & I can properly respond to a customer's specific conditions & 2.83 & 1.13 & 10.88 & 0.81 \\
\hline Solution quality & Solutions found for my customers' problems are usually high-quality solutions & 2.70 & 1.12 & & 0.80 \\
\hline (Atuahene-Gima, & Solutions found usually respond exactly to my customers' needs & 2.63 & 1.17 & 13.93 & 0.87 \\
\hline $\begin{array}{l}\text { 2003; Madhavaram } \\
\text { and Hunt, 2017) }\end{array}$ & Solutions found for customers' encountered problems are usually effective & 3.08 & 1.13 & 13.30 & 0.83 \\
\hline Firm performance & \multicolumn{5}{|c|}{ Please indicate your firm's performance relative to all other competitors in the primary market that you serve: } \\
\hline (Tajvidi and Karami, & Increase in market share over the past 3 years & 2.48 & 1.09 & & 0.79 \\
\hline \multirow[t]{4}{*}{ 2017) } & Increase in annual turnover over the past 3 years & 2.59 & 1.00 & 19.63 & 0.83 \\
\hline & Profit over the past 3 years & 2.54 & 0.99 & 21.65 & 0.91 \\
\hline & Return on investment over the past 3 years & 2.62 & 0.98 & 15.82 & 0.89 \\
\hline & Total income over the past 3 years & 2.57 & 1.06 & 16.09 & 0.88 \\
\hline
\end{tabular}


Table 2 Means, standard deviations, composite reliability and discriminant validity test[

\begin{tabular}{lcccccccr}
\hline Constructs & Mean & SD & CR & $\mathbf{1}$ & $\mathbf{2}$ & $\mathbf{3}$ & $\mathbf{4}$ & $\mathbf{5}$ \\
\hline 1. Source credibility & 2.91 & 0.93 & 0.86 & 0.67 & & & & \\
2. Content quality & 3.22 & 1.09 & 0.89 & 0.25 & 0.73 & & & \\
3. Self-efficacy & 2.57 & 1.08 & 0.87 & 0.19 & 0.14 & 0.63 & & \\
4. Solution quality & 2.80 & 1.14 & 0.87 & 0.19 & 0.15 & 0.14 & 0.69 & \\
5. Firm performance & 2.56 & 1.02 & 0.93 & 0.36 & 0.24 & 0.27 & 0.30 & 0.74
\end{tabular}

Notes: Diagonal entries are the average variances extracted; entries below the diagonal are squared correlations (all correlations were significant at the 0.01 level); CR: composite reliability

validity and discriminant validity were achieved (Fornell and Larcker, 1981).

\section{Results}

The results of the structural model estimation (Table 3) indicate a good model fit. Chi-square $(d f=129)$ was equal to 285.62 , with a $\chi^{2} / d f$ ratio of 2.21 , below the cut-off value of 3 (Kline, 2011). In addition, CFI was 0.94, above the threshold of 0.93 (Bagozzi and Yi, 2012). RMSEA was 0.07, showing a good model fit (Bagozzi and Yi, 2012).

The results show that both source credibility $(\beta=0.599, p<$ $0.01)$ and content quality $(\beta=0.193, p<0.01)$ were positively related to a professional's self-efficacy. Therefore, $H 1$ and $H 2$ are supported. In addition, service self-efficacy positively affected both solution quality $(\beta=0.559, p<0.01)$ and firm performance $(\beta=0.556, p<0.01)$. Hence, $H 3$ and $H 4$ are also supported. Finally, the findings indicate that solution quality had a positive effect on firm performance $(\beta=0.329, p<$ 0.01 ), supporting $H 5$. With respect to the frequency of social media usage, which was included as a control variable, no significant effect emerged.

Additionally, we assessed the significance of indirect effects by using bootstrapping (500 replications). The indirect effects of source credibility on both solution quality $(\beta=0.335, p<$
$0.01)$ and firm performance $(\beta=0.443, p<0.01)$ were significant. Similarly, the indirect effects of content quality on both solution quality $(\beta=0.108, p<0.05)$ and firm performance $(\beta=0.143, p<0.05)$ were significant. These findings provide evidence for the mediating role of self-efficacy.

\section{Discussion}

\subsection{Theoretical implications}

The findings of this study contribute to the available knowledge about the value creation process and outcomes of PSFs in several ways. First, the central role of self-efficacy highlighted in this study contributes to advancing available knowledge on the mechanisms through which knowledge absorbed from external sources affects PSF performance (Khaksar et al., 2020). In fact, prior research (Siahtiri et al., 2020) has suggested that professionals' access to external knowledge may enhance the value creation process and overall performance by increasing professionals' technical competency. The present research has found an alternative explanation, centred on professionals' beliefs. The findings indicate that professionals' access to external sources positively influences PSF outcomes by strengthening professionals' beliefs about self-efficacy. These findings, rooted in self-efficacy theory, are consistent with the people-centred nature of the PSF value creation process (McColl-Kennedy et al., 2008) and the notion that outcomes are related to emotions such as uncertainty and anxiety (Aarikka-Stenroos and Jaakkola, 2012). In other words, by strengthening professionals' self-efficacy, external source content may mitigate the effect of negative beliefs (Bandura, 1977).

The findings also highlight the beneficial impacts of highquality content accessed through credible external sources on professionals' attitudes and PSF outcomes (solution quality and firm performance). While this result is consistent with past research conducted in other fields indicating that source credibility and content quality are antecedents of user engagement and intention to comply with suggestions provided by external sources (Dedeoglu, 2019; Magno, 2017), specific

Table 3 Structural model

\begin{tabular}{|c|c|c|c|}
\hline Effects & Unstandardised coefficient & Standard error & Standardised coefficient \\
\hline \multicolumn{4}{|l|}{ Direct effects } \\
\hline Source credibility $\rightarrow$ Self-efficacy & $0.564^{* *}$ & 0.081 & 0.599 \\
\hline Content quality $\rightarrow$ Self-efficacy & $0.187^{* *}$ & 0.069 & 0.193 \\
\hline Self-efficacy $\rightarrow$ Solution quality & $0.635^{* *}$ & 0.094 & 0.559 \\
\hline Self-efficacy $\rightarrow$ Firm performance & $0.655^{* *}$ & 0.091 & 0.556 \\
\hline Solution quality $\rightarrow$ Firm performance & $0.341^{* *}$ & 0.070 & 0.329 \\
\hline \multicolumn{4}{|l|}{ Indirect effects } \\
\hline Source credibility $\rightarrow$ Self-efficacy $\rightarrow$ Solution quality & $0.358^{* *}$ & 0.059 & 0.335 \\
\hline Source credibility $\rightarrow$ Self-efficacy $\rightarrow$ Firm performance & $0.492^{* *}$ & 0.068 & 0.443 \\
\hline Content quality $\rightarrow$ Self-efficacy $\rightarrow$ Solution quality & $0.119^{*}$ & 0.047 & 0.108 \\
\hline Content quality $\rightarrow$ Self-efficacy $\rightarrow$ Firm performance & $0.163^{*}$ & 0.058 & 0.143 \\
\hline \multicolumn{4}{|l|}{ Model fit } \\
\hline$\chi^{2}$ & \multicolumn{2}{|l|}{$285.62, \mathrm{df}=129, p<0.01$} & \\
\hline RMSEA & \multicolumn{2}{|l|}{$0.07[0.06-0.08]$} & \\
\hline CFI & \multicolumn{2}{|l|}{0.94} & \\
\hline
\end{tabular}


explanations related to PSFs can be added. For PSFs, the risks associated with failure in delivering successful solutions are high (Heirati et al., 2016). To avoid the trap of failure, it is essential that professionals carefully select the knowledge they access (Siahtiri et al., 2020). These arguments help to explain why professionals are more likely to engage with content provided by external sources if the source is perceived as credible and the content as having high quality.

Moreover, the findings provide further evidence that the PSF value creation process may benefit from exchanges of professional content among peers. As highlighted by the theory of self-efficacy, observing the experiences of peers who have developed solutions for similar problems and receiving suggestions and feedback from peers about a specific problem have beneficial effects on performance (Bandura, 1999). The results of this study can be understood by considering findings from recent research about knowledge exchange in communities of practice, such as the sales forums used by salespeople (Conde et al., 2020). By exchanging information, forum participants gain support to overcome doubts and anxiety. Our research suggests that these processes can be extended to PSF professionals. Again, access to content exchanged among peers and to communities of practice provides not only functional benefits (new knowledge or technical tips to address problems) but also emotional benefits. One of the main issues for PSF professionals is defining and redefining professional identity (Brouard et al., 2017; Golyagina and Valuckas, 2020). Having access to professional content from peers and experiencing peers' support facilitates the psychological process through which professionals construct and maintain their professional identity, thus strengthening self-concept and self-esteem.

Additional insights can be derived by considering the specific channel of communication considered to test the empirical model; namely, professional social media. Compared with the face-to-face and peer-to-peer interactions analysed in prior research (Brandon-Jones et al., 2016; Hitt et al., 2001), professional social media provides professionals with the opportunity to participate in significantly larger networks to reach distal knowledge (Siahtiri et al., 2020). On this point, the theory on technological platforms emphasises that interactions and exchanges among actors can be accelerated by such platforms, thus enhancing the business model and value creation processes (Rodríguez et al., 2020). By engaging on these platforms, firms can access knowledge outside their own boundaries and integrate this with their internal knowledge to improve value creation (Andreassen et al., 2018; Lichtenthaler and Lichtenthaler, 2009). By having access to a large number of peers through technological platforms, professionals may be more likely to make contact with other professionals who have experienced similar niche problems and can therefore act as models (vicarious experience) or providers of valuable suggestions and feedback (verbal persuasion). Hence, by observing how others have successfully coped with similar tasks or by asking for advice on or discussing specific issues with peers, professionals participate in transactions (Kolb and Kolb, 2009) and receive informational support that makes them feel more confident in finding specific solutions for their customers' problems.

\subsection{Managerial implications}

The findings provide actionable insights for practice for professionals, professional associations and other social actors involved in exchanging professional content. The results indicate that professionals may derive benefits by engaging with content from external sources. Therefore, the findings suggest interesting opportunities for professional associations, which in recent decades have witnessed significant changes in their respective fields and shifts in the boundaries of their professions, as well as a deterioration of power (Greenwood et al., 2005). First, professional associations could act to reduce professionals' resistance to engaging with external sources of knowledge by demonstrating the potential benefits for PSF performance. For example, the specific communication channel considered in this empirical study - namely, professional social media - is currently adopted only $40 \%$ of professionals who completed the questionnaire. This may be attributable to the resistance of professionals to consider new communication channels, the limited availability of such channels and the difficulty in ascertaining content quality and source reliability. Professional associations could offer training courses, not only convey technical knowledge about specific communication channels and platforms but also practically demonstrate the benefits of using these, such as sharing knowledge, identifying a colleague with whom to collaborate on specific projects and establishing relationships.

Professional associations could create and share high-quality content relevant to professionals by observing and incorporating concepts and information discussed and exchanged among peers. They could also offer specific channels of communication, such as platforms or social media pages through which their members could interact. Moreover, they could evaluate the opportunity to act as endorsers of thirdparty information providers and platforms, for which they guarantee the quality and reliability of content. By reassuring professionals about source credibility and content quality, professional associations may reinforce their bonds with members and gain centrality in supporting the development of high-quality solutions. These actions could both bring benefits to members and help organisations take the lead in shaping professionals' identity formation (Brouard et al., 2017; Thorne, 2017).

The creation and exchange of professional content is also occasionally led by other actors such as professionals with significant reputations in the field, bloggers or other actors such as providers of professional magazines and databases. These actors should all focus on credibility and content quality, thus creating a bond of trust with users and followers. To achieve this purpose, they could also evaluate the opportunity to cooperate with professional associations.

\subsection{Limitations and future directions}

While the findings of this paper shed light on the psychological mechanisms through which knowledge acquired from external sources affects PSF outcomes, several limitations should be addressed before extending the findings.

This paper provides an explanation of these effects based on professionals' beliefs instead of technical competencies, as indicated in prior research. Future studies could integrate the two approaches to gain a wider understanding of the role of 
both emotions and competencies in the effects of external knowledge on PSF outcomes.

The suggested model was only tested for specific types of PSF, namely, accounting and law firms. Applying this model to all categories of knowledge-intensive firms (Von Nordenflycht, 2010) may represent an avenue for future studies. Further, the sample mostly consisted of micro- and small-sized PSFs in the Italian context. Therefore, the findings cannot be directly applied to large, bureaucratised PSFs (Brivot, 2011).

Only one specific communication channel was considered in the empirical study, namely, professional social media. Extending the research to other channels (e.g. comparing traditional communication channels and technological platforms) could provide new insights. Moreover, professional social media, excluding mixed $\mathrm{B} 2 \mathrm{C} / \mathrm{B} 2 \mathrm{~B}$ and pure $\mathrm{B} 2 \mathrm{C}$ social media (Iankova et al., 2019), was considered without distinguishing between different types, such as blogs or social networks (Kaplan and Haenlein, 2010). There was also no discrimination between personal blogs and those sponsored by official associations. Future studies may address these distinctions to identify the existence of moderating effects.

It may also be interesting to investigate the antecedents of professionals' intention to offer advice to other professionals, which may be conceptualised as a coopetition strategy, i.e. as an interplay between cooperation and competition (Crick, 2020). Again, future research could explore knowledge-sharing behaviours among professionals by comparing face-to-face interactions and interactions via technological platforms.

Finally, at a broader level, the findings of this study may suggest new research opportunities related to content sharing among peers in B2B settings. In fact, B2B research has focused mostly on firm's creation and sharing of content with customers, potential employees, suppliers and other stakeholders (Andersson and Wikström, 2017; Magno and Cassia, 2020), while the dimension of peer-to-peer knowledge exchange, especially through platforms, has been largely overlooked.

\section{References}

Aarikka-Stenroos, L. and Jaakkola, E. (2012), "Value cocreation in knowledge intensive business services: a dyadic perspective on the joint problem solving process", Industrial Marketing Management, Vol. 41 No. 1, pp. 15-26.

Aladwani, A.M. (2017), "Compatible quality of social media content: conceptualization, measurement, and affordances", International fournal of Information Management, Vol. 37 No. 6, pp. 576-582.

Anderson, C. (2006), The Long Tail: Why the Future of Business is Selling More for Less, Hyperion, New York, NY.

Andersson, S. and Wikström, N. (2017), "Why and how are social media used in a B2B context, and which stakeholders are involved?", Fournal of Business \& Industrial Marketing, Vol. 32 No. 8, pp. 1098-1108.

Anderson, D.W., Krajewski, H.T., Goffin, R.D. and Jackson, D.N. (2008), "A leadership self-efficacy taxonomy and its relation to effective leadership", The Leadership Quarterly, Vol. 19 No. 5, pp. 595-608.

Andreassen, T.W., Lervik-Olsen, L., Snyder, H., Van Riel, A. C., Sweeney, J.C. and Van Vaerenbergh, Y. (2018),
"Business model innovation and value-creation: the triadic way", Fournal of Service Management, Vol. 29 No. 5, pp. 883-906.

Armstrong, J.S. and Overton, T.S. (1977), "Estimating nonresponse bias in mail surveys", fournal of Marketing Research, Vol. 14 No. 3, pp. 396-402.

Asare, E.K., Whittington, J.L. and Walsh, R. (2020), "Promoting desirable work attitudes and behaviors among accountants: a field study", fournal of Business E Industrial Marketing, Vol. 35 No. 10, pp. 1-14.

Atuahene-Gima, K. (2003), "The effects of centrifugal and centripetal forces on product development speed and quality: how does problem solving matter?", Academy of Management fournal, Vol. 46 No. 3, pp. 359-373.

Bagozzi, R.P. and Yi, Y. (2012), "Specification, evaluation, and interpretation of structural equation models", fournal of the Academy of Marketing Science, Vol. 40 No. 1, pp. 8-34.

Bandura, A. (1977), "Self-efficacy: toward a unifying theory of behavioral change", Psychological Review, Vol. 84 No. 2, pp. 191-215.

Bandura, A. (1986), "The explanatory and predictive scope of self-efficacy theory", fournal of Social and Clinical Psychology, Vol. 4 No. 3, pp. 359-373.

Bandura, A. (1999), Self-Efficacy: The Exercise of Control, W.H. Freeman and Company, New York, NY.

Bandura, A., Adams, N.E. and Beyer, J. (1977), "Cognitive processes mediating behavioral change", Fournal of Personality and Social Psychology, Vol. 35 No. 3, p. 125.

Barney, J. (1991), "Firm resources and sustained competitive advantage", fournal of Management, Vol. 17 No. 1, pp. 99-120.

Bettencourt, L.A., Ostrom, A.L., Brown, S.W. and Roundtree, R.I. (2002), "Client co-production in knowledge-intensive business services”, California Management Review, Vol. 44 No. 4, pp. 100-128.

Bhattacherjee, A. and Sanford, C. (2006), "Influence processes for information technology acceptance: an elaboration likelihood model", MIS Quarterly, Vol. 30 No. 4, pp. 805-825.

Blair, A., Key, T.M. and Wilson, M. (2019), "Crowdsourcing to manage service gaps in service networks", fournal of Business and Industrial Marketing, Vol. 34 No. 7, pp. 1497-1505, doi: 10.1108/JBIM-12-2018-0387.

Bohner, G. and Dickel, N. (2011), "Attitudes and attitude change", Annual Review of Psychology, Vol. 62 No. 1, pp. 391-417.

Brandon-Jones, A., Lewis, M., Verma, R. and Walsman, M.C. (2016), "Examining the characteristics and managerial challenges of professional services: an empirical study of management consultancy in the travel, tourism, and hospitality sector", fournal of Operations Management, Vols 42/43 No. 1, pp. 9-24.

Brivot, M. (2011), "Controls of knowledge production, sharing and use in bureaucratized professional service firms", Organization Studies, Vol. 32 No. 4, pp. 489-508.

Brouard, F., Bujaki, M., Durocher, S. and Neilson, L.C. (2017), "Professional accountants' identity formation: an integrative framework", Fournal of Business Ethics, Vol. 142 No. 2, pp. 225-238. 
Brown, S.P., Jones, E. and Leigh, T.W. (2005), "The attenuating effect of role overload on relationships linking self-efficacy and goal level to work performance", fournal of Applied Psychology, Vol. 90 No. 5, pp. 972-979.

Casidy, R., Nyadzayo, M.W., Mohan, M. and Brown, B. (2018), "The relative influence of functional versus imagery beliefs on brand sensitivity in B2B professional services", Industrial Marketing Management, Vol. 72, pp. 26-36.

Cassia, F. and Magno, F. (2012), "Business-to-Business branding: a review and assessment of the impact of nonattribute-based brand beliefs on buyer's attitudinal loyalty", Canadian fournal of Administrative Sciences/Revue Canadienne Des Sciences de L'administration, Vol. 29 No. 3, pp. 242-254.

Castaldi, C. and Giarratana, M.S. (2018), "Diversification, branding, and performance of professional service firms", Fournal of Service Research, Vol. 21 No. 3, pp. 353-364.

Censis (2018), "Percorsi e scenari dell'avvocatura italiana", Rapporto 2018, available at: www.cassaforense.it/media/ 7191/rapporto-censis-2018.pdf"

Conde, R., Prybutok, V. and Sumlin, C. (2020), "The utilization of online sales forums by salespeople as a mesosystem for enhancing sales-activity knowledge", fournal of Business $\mathcal{E}$ Industrial Marketing, pp. 1-11.

Cosenza, T.R., Solomon, M.R. and Kwon, W.K. (2015), "Credibility in the blogosphere: a study of measurement and influence of wine blogs as an information source", fournal of Consumer Behaviour, Vol. 14 No. 2, pp. 71-91.

Crick, J.M. (2020), "Unpacking the relationship between a coopetition-oriented mindset and coopetition-oriented behaviours", Fournal of Business E Industrial Marketing, Vol. 36 No. 3, pp. 1-20.

Cutrona, C.E. (1990), "Stress and social support-in search of optimal matching", fournal of Social and Clinical Psychology, Vol. 9 No. 1, pp. 3-14.

Cutrona, C.E. and Russell, D.W. (1990), "Type of social support and specific stress: toward a theory of optimal matching", in Sarason, B. R., Sarason, I. G. and Pierce, G. R. (Eds), Social Support: An Interactional View, Wiley, New York, NY, pp. 319-366.

Dedeoglu, B.B. (2019), "Are information quality and source credibility really important for shared content on social media?", International fournal of Contemporary Hospitality Management, Vol. 31 No. 1, pp. 513-534.

Desyllas, P., Miozzo, M., Lee, H. F. and Miles, I. (2018), "Capturing value from innovation in knowledge-intensive business service firms: the role of competitive strategy", British Fournal of Management, Vol. 29 No. 4, pp. 769-795.

FNC (2018), "Indagine statistica 2018 sui dottori commercialisti ed esperti contabili", available at: www. fondazionenazionalecommercialisti.it/node/1326

Fornell, C. and Larcker, D.F. (1981), "Evaluating structural equation models with unobservable variables and measurement error", fournal of Marketing Research, Vol. 18 No. 1, pp. 39-50.

Fosstenløkken, S.M., Løwendahl, B.R. and Revang, Ø. (2003), "Knowledge development through client interaction: a comparative study", Organization Studies, Vol. 24 No. 6, pp. 859-879.

Fu, N., Bosak, J., Flood, P.C. and Ma, Q. (2019), "Chinese and Irish professional service firms compared: linking
HPWS, organizational coordination, and firm performance", Fournal of Business Research, Vol. 95, pp. 266-276.

Fu, F.Q., Richards, K.A., Hughes, D.E. and Jones, E. (2010), "Motivating salespeople to sell new products: the relative influence of attitudes, subjective norms, and self-efficacy", Fournal of Marketing, Vol. 74 No. 6, pp. 61-76.

Gist, M.E. (1987), "Self-efficacy: implications for organizational behavior and human resource management", Academy of Management Review, Vol. 12 No. 3, pp. 472-485.

Golyagina, A. and Valuckas, D. (2020), "Boundary-work in management accounting: the case of hybrid professionalism", The British Accounting Review, Vol. 52 No. 2, p. 100841

Grant, R.M. (1996), "Toward a knowledge-based theory of the firm", Strategic Management fournal, Vol. 17 No. S2, pp. 109-122.

Grant, R.M. (1999), "Prospering in dynamically-competitive environments: organizational capability as knowledge integration", Knowledge and Strategy, Elsevier, pp. 133-153.

Greenwood, R., Li, S.X., Prakash, R. and Deephouse, D.L. (2005), "Reputation, diversification, and organizational explanations of performance in professional service firms", Organization Science, Vol. 16 No. 6, pp. 661-673.

Grönroos, C. (2011), “A service perspective on business relationships: the value creation, interaction and marketing interface", Industrial Marketing Management, Vol. 40 No. 2, pp. 240-247.

Guan, M. and So, J. (2016), "Influence of social identity on self-efficacy beliefs through perceived social support: a social identity theory perspective", Communication Studies, Vol. 67 No. 5, pp. 588-604.

Hair, J.F., Ringle, C.M. and Sarstedt, M. (2011), "PLS-SEM: indeed a silver bullet", fournal of Marketing Theory and Practice, Vol. 19 No. 2, pp. 139-151.

Hartline, M.D. and Ferrell, O.C. (1996), "The management of customer-contact service employees: an empirical investigation", Fournal of Marketing, Vol. 60 No. 4, pp. 52-70.

Hausman, A.V. (2003), "Professional service relationships: a multi-context study of factors impacting satisfaction, repatronization, and recommendations", fournal of Services Marketing, Vol. 17 No. 3, pp. 226-242.

Heikka, E.-L. and Nätti, S. (2018), "Evolving value propositions in knowledge-intensive business services", Fournal of Business E Industrial Marketing, Vol. 33 No. 8, pp. 1153-1164.

Heirati, N., Henneberg, S.C., Richter, A. and Harste, R. (2019), "Differential importance of social and economic determinants of relationship performance in professional services", Industrial Marketing Management, Vol. 76, pp. 23-35.

Heirati, N., O'Cass, A., Schoefer, K. and Siahtiri, V. (2016), "Do professional service firms benefit from customer and supplier collaborations in competitive, turbulent environments?", Industrial Marketing Management, Vol. 55, pp. 50-58.

Hitt, M.A., Bierman, L., Shimizu, K. and Kochhar, R. (2001), "Direct and moderating effects of human Capital on strategy and performance in professional service firms: a resource- 
based perspective", Academy of Management fournal, Vol. 44 No. 1, pp. 13-28.

Hogan, S.J., Soutar, G.N., McColl-Kennedy, J.R. and Sweeney, J.C. (2011), "Reconceptualizing professional service firm innovation capability: scale development", Industrial Marketing Management, Vol. 40 No. 8, pp. 1264-1273.

Iankova, S., Davies, I., Archer-Brown, C., Marder, B. and Yau, A. (2019), "A comparison of social media marketing between B2B, B2C and mixed business models", Industrial Marketing Management, Vol. 81, pp. 169-179.

Jaakkola, E. and Halinen, A. (2006), "Problem solving within professional services: evidence from the medical field", International fournal of Service Industry Management, Vol. 17 No. 5, pp. 409-429.

Kaplan, A.M. and Haenlein, M. (2010), "Users of the world, unite! The challenges and opportunities of social media", Business Horizons, Vol. 53 No. 1, pp. 59-68.

Khaksar, S.M.S., Chu, M.-T., Rozario, S. and Slade, B. (2020), "Knowledge-based dynamic capabilities and knowledge worker productivity in professional service firms the moderating role of organisational culture", Knowledge Management Research E Practice, pp. 1-18.

Khedhaouria, A., Gurău, C. and Torrès, O. (2015), "Creativity, self-efficacy, and small-firm performance: the mediating role of entrepreneurial orientation", Small Business Economics, Vol. 44 No. 3, pp. 485-504.

Kim, S., Kandampully, J. and Bilgihan, A. (2018), "The influence of eWOM communications: an application of online social network framework", Computers in Human Behavior, Vol. 80, pp. 243-254.

Kline, R.B. (2011), Principles and Practice of Structural Equation Modeling, 3rd ed., Guilford, New York, NY.

Kolb, A.Y. and Kolb, D.A. (2009), "Experiential learning theory: a dynamic, holistic approach to management learning, education and development", in Armstrong, S. J. and Fukami, C. V. (Eds), The SAGE Handbook of Management Learning, Education and Development, Sage, London, pp. 42-68.

Lee, K.-J. (2014), "Attitudinal dimensions of professionalism and service quality efficacy of frontline employees in hotels", International fournal of Hospitality Management, Vol. 41, pp. 140-148.

Liang, B. (2019), "The effects of self-efficacy, process feedback, and task complexity on escalation of commitment in new product development", Fournal of Business $\mathcal{E}$ Industrial Marketing, Vol. 34 No. 8, pp. 1641-1653.

Lichtenthaler, U. and Lichtenthaler, E. (2009), “A capabilitybased framework for open innovation: complementing absorptive capacity", Fournal of Management Studies, Vol. 46 No. 8, pp. 1315-1338.

Løwendahl, B.R. (2005), Strategic Management of Professional Service Firms, Copenhagen Business School Press, Copenhagen.

Løwendahl, B.R., Revang, Ø. and Fosstenløkken, S.M. (2001), "Knowledge and value creation in professional service firms: a framework for analysis", Human Relations, Vol. 54 No. 7, pp. 911-931.

McColl-Kennedy, J.R., Sweeney, J.C., Soutar, G.N. and Amonini, C. (2008), "Professional service firms are relationship marketers: but does size matter?", Australasian Marketing fournal, Vol. 16 No. 1, pp. 30-47.

Macdonald, E.K., Kleinaltenkamp, M. and Wilson, H.N. (2016), "How business customers judge solutions: solution quality and value in use", fournal of Marketing, Vol. 80 No. 3, pp. 96-120.

Madhavaram, S. and Hunt, S.D. (2017), "Customizing business-to-business (B2B) professional services: the role of intellectual capital and internal social capital", fournal of Business Research, Vol. 74, pp. 38-46.

Magno, F. (2017), "The influence of cultural blogs on their readers' cultural product choices", International fournal of Information Management, Vol. 37 No. 3, pp. 142-149.

Magno, F. and Cassia, F. (2020), "Establishing thought leadership through social media in B2B settings: effects on customer relationship performance", Fournal of Business \& Industrial Marketing, Vol. 35 No. 3, pp. 437-446.

Miles, I. (1993), "Services in the new industrial economy", Futures, Vol. 25 No. 6, pp. 653-672.

Nguyen, B., Yu, X., Melewar, T. and Chen, J. (2015), "Brand innovation and social media: knowledge acquisition from social media, market orientation, and the moderating role of social media strategic capability", Industrial Marketing Management, Vol. 51, pp. 11-25.

Nickerson, J.A. and Zenger, T.R. (2004), “A knowledge-based theory of the firm - the problem-solving perspective", Organization Science, Vol. 15 No. 6, pp. 617-632.

Paschen, J., Pitt, L. and Kietzmann, J. (2019), "Emerging technologies and value creation in business and industrial marketing", fournal of Business E Industrial Marketing, Vol. 34 No. 7, pp. 1401-1402.

Pemer, F. and Skjølsvik, T. (2019), "The cues that matter: screening for quality signals in the ex ante phase of buying professional services", fournal of Business Research, Vol. 98, pp. 352-365.

Podsakoff, P.M., MacKenzie, S.B., Lee, J.Y. and Podsakoff, N. P. (2003), "Common method biases in behavioral research: a critical review of the literature and recommended remedies", Fournal of Applied Psychology, Vol. 88 No. 5, pp. 879-903.

Poon, J.M., Ainuddin, R.A. and Junit, S.O.H. (2006), "Effects of self-concept traits and entrepreneurial orientation on firm performance", International Small Business fournal: Researching Entrepreneurship, Vol. 24 No. 1, pp. 61-82.

Robinson, L., Jr, Neeley, S.E. and Williamson, K. (2011), "Implementing service recovery through customer relationship management: identifying the antecedents", Fournal of Services Marketing, Vol. 25 No. 2, pp. 90-100.

Rodríguez, R., Molina-Castillo, F.-J. and Svensson, G. (2020), "The mediating role of organizational complexity between enterprise resource planning and business model innovation", Industrial Marketing Management, Vol. 84, pp. 328-341.

Schmenner, R.W. (1986), "How can service businesses survive and prosper?", Sloan Management Review, Vol. 27 No. 3, pp. 21-32.

Schunk, D.H. (1989), "Self-efficacy and achievement behaviors", Educational Psychology Review, Vol. 1 No. 3, pp. 173-208. 
Siahtiri, V., Heirati, N. and O'Cass, A. (2020), "Unlocking solution provision competence in knowledge-intensive business service firms”, Industrial Marketing Management, Vol. 87, pp. 117-127.

Still, J., Komulainen, H. and Nätti, S. (2018), "Contextual layers of service experience in professional business services", Fournal of Business \& Industrial Marketing, Vol. 33 No. 8, pp. 1114-1124.

Sturdy, A. (1997), "The consultancy process-an insecure business?", Fournal of Management Studies, Vol. 34 No. 3, pp. 389-413.

Tajvidi, R. and Karami, A. (2017), "The effect of social media on firm performance", Computers in Human Behavior.

Thorne, L. (2017), "Discussion of "a theoretical framework of professional accountants' identity formation and directions for future research", Fournal of Business Ethics, Vol. 142 No. 2, pp. 239-240.

Van Beuningen, J., De Ruyter, K. and Wetzels, M. (2011), "The power of self-efficacy change during service provision: making your customers feel better about themselves pays off”, fournal of Service Research, Vol. 14 No. 1, pp. 108-125.

Vargo, S.L. and Lusch, R.F. (2016), "Institutions and axioms: an extension and update of service-dominant logic", fournal of the Academy of Marketing Science, Vol. 44 No. 1, pp. 5-23.

Verma, R. (2000), "An empirical analysis of management challenges in service factories, service shops, mass services and professional services", International fournal of Service Industry Management, Vol. 11 No. 1, pp. 8-25.

Von Nordenflycht, A. (2010), "What is a professional service firm? Toward a theory and taxonomy of knowledge-intensive firms", Academy of Management Review, Vol. 35 No. 1, pp. 155-174.
Wang, Y., Hsiao, S.-H., Yang, Z. and Hajli, N. (2016), "The impact of sellers' social influence on the co-creation of innovation with customers and brand awareness in online communities", Industrial Marketing Management, Vol. 54, pp. 56-70.

Warren, S. and Parker, L. (2009), "Bean counters or bright young things? Towards the visual study of identity construction among professional accountants", Qualitative Research in Accounting \& Management, Vol. 6 No. 4, pp. 205-223.

Willemsen, L.M., Neijens, P.C. and Bronner, F. (2012), "The ironic effect of source identification on the perceived credibility of online product reviewers", fournal of ComputerMediated Communication, Vol. 18 No. 1, pp. 16-31.

Xie, C., Bagozzi, R.P. and Troye, S.V. (2008), "Trying to prosume: toward a theory of consumers as co-creators of value", Fournal of the Academy of Marketing Science, Vol. 36 No. 1, pp. 109-122.

Yim, C.K., Chan, K.W. and Lam, S.S. (2012), "Do customers and employees enjoy service participation? Synergistic effects of self-and other-efficacy", fournal of Marketing, Vol. 76 No. 6, pp. 121-140.

Zha, X., Yang, H., Yan, Y., Liu, K. and Huang, C. (2018), "Exploring the effect of social media information quality, source credibility and reputation on informational fit-to-task: moderating role of focused immersion", Computers in Human Behavior, Vol. 79, pp. 227-237.

Zhang, J. and Du, M. (2020), "Utilization and effectiveness of social media message strategy: how B2B brands differ from B2C brands", Fournal of Business \& Industrial Marketing, Vol. 35 No. 4, pp. 721-740.

\section{Corresponding author}

Fabio Cassia can be contacted at: fabio.cassia@univr.it 